\title{
POTRZEBA REKONCEPTUALIZACJI WCZESNOŚREDNIOWIECZNYCH POCHÓWKÓW „WAMPIRÓW" Z ZIEM POLSKICH
}

\author{
THE NEED OF RECONCEPTUALIZATION \\ OF EARLY MEDIEVAL BURIALS \\ OF "VAMPIRES" FROM POLAND
}

\author{
Olga Dec \\ Wydział Archeologii, Uniwersytet Adama Mickiewicza \\ ul. Uniwersytetu Poznańskiego 7, 61-614 Poznań \\ olga.dec@amu.edu.pl
}

\begin{abstract}
The aim of the article is to outline the need to reconceptualized the early medieval burials of "vampires" from Poland. These burials are understood as the remains of the so-called "anti-vampire" practices resulting from the social perception of bad death. These, in turn, are recognized as a socio-religious phenomenon, the assumption of which was to postpone the evil actions of the 'vampire' by means of certain measures. Due to doubts about the term "vampire", concerning both the linguistic sphere and the cultural and historical realities, it is suggested not to use it. The proposed alternative, more precise terms would therefore be the terms "returning dead" or "(un)dead". Another issue raised is the setting of 'anti-vampire' burials in an atypical framework. "Anti-vampirical" burials meet the criteria of atypicality on a macro scale, however, it is possible to consider them typical, assuming that they functioned in the culture of Western Slavs in the early Middle Ages as belonging to a specific social group.
\end{abstract}

KEY WORDS: anti-vampire graves, atypical graves, Western Slavs, vampires, early Middle Ages

Założeniem niniejszego artykułu jest zarysowanie potrzeby rekonceptualizacji problematyki wczesnośredniowiecznych grobów „wampirów” z ziem polskich. Po pierwsze dotyczy to odejścia od „wampiryzmu” w proponowanych interpretacjach, jako że określenie to jest kontrowersyjne. Zdaje się mieć ponadto mało wspólnego z realiami zarówno językowymi, jak i kulturowymi wczesnośredniowiecznej Sło- 
wiańszczyzny ${ }^{1}$. Po drugie jest to przemyślenie związku między pochówkami „,antywampirycznymi" a atypowymi. Jako że te pierwsze dotyczą jasno określonej grupy społecznych odszczepieńców, warte rozważenia jest uznanie ich za, w pewnym sensie, typowe.

\section{POCHÓWKI „ANTYWAMPIRYCZNE”, POCHÓWKI ATYPOWE}

Najprostsza, lecz wyczerpująca definicja tego, czym są pochówki atypowe, zawiera się w stwierdzeniu, że są to wszystkie te pochówki, które odbiegają od tego, co w nauce uznaje się za normatywne dla danej społeczności, miejsca i czasu w aspekcie zachowań funeralnych. Tak też określenie znaczenia, a w dalszej kolejności tego, czym się przejawia atypowość, możliwe staje się jedynie na drodze zestawienia z uprzednio zdefiniowaną „typowością” (Aspöck, 2008).

Specyficznym rodzajem pochówków atypowych na obszarach Słowiańszczyzny zachodniej są tzw. pochówki ,antywampiryczne”. W materiale archeologicznym zauważalne są dopiero od momentu wprowadzenia chrześcijaństwa ze względu na towarzyszący mu obrządek inhumacyjny, a ich największa liczba przypada na wiek XI (Żydok, 2004). Spełniają przy tym warunki atypowości, odbiegając od tego, co uznaje się za standardowy dla wczesnego średniowiecza sposób grzebania zmarłych (obrządek szkieletowy, zmarli w pozycji wyprostowanej na wznak, z wyprostowanymi kończynami). Z kolei tym, co charakteryzuje je na tle ogólnego zbioru pochówków atypowych, to występowanie widocznych śladów związanych z zastosowaniem określonych praktyk prewencyjnych. Zalicza się do nich (Zoll-Adamikowa, 1971, s. 5052; Żydok, 2004; Stanaszek, 2016, s. 73): ułożenie szczątków na brzuchu lub na boku (wówczas w pozycji skurczonej), krępowanie ciała, przywalanie szczątków kamieniami (głównie okolic głowy, piersi lub nóg) lub układanie kamieni nad pochówkiem, zatykanie ust kamieniem, gliną, rzadziej monetą, celowe uszkadzanie szczątków (przebijanie głowy, piersi ostrymi przedmiotami), odcinanie głowy i częściowe palenie szczątków. Śladami sugerującymi zastosowanie zabiegów „antywampirycznych” są także wtórne otwieranie grobu, brak wyposażenia grobowego, peryferyczne ulokowanie grobu (na obrzeżach cmentarza lub poza jego obrębem), odmienna orientacja szczątków względem stron świata i głębsza (od pozostałych na stanowisku) jama grobowa. W części przytoczonych praktyk upatruje się chęci ponownego zabicia „wampira" lub utrudnienia czy uniemożliwienia mu wydostania się z grobu. Tym samym praktyki „antywampiryczne” rozumieć można jako szczególne zjawisko społeczno-religijne, którego założeniem było odsuwanie za pomocą pewnych zabiegów złych działań „wampira”. Mając to na uwadze, zarówno praktyki „,antywampiryczne”, jak

\footnotetext{
${ }^{1}$ Odnosząc się do tej formy pochówków, tam, gdzie jest to niezbędne, zamierzam konsekwentnie stosować terminy: „pochówek antywampiryczny”, „grób antywampiryczny” oraz „wampir”, zapisując je w cudzysłowie. Ma to na celu podkreślenie sceptycyzmu dotyczącego tej dyskusyjnej terminologii, która jest jednak rozpowszechniona w literaturze przedmiotu, a tym samym trudna do całkowitego pominięcia.
} 
i bezpośrednio będące ich efektem pochówki należy ujmować jako szczególny rodzaj recepcji śmierci - w tym przypadku: śmierci złej. Śmierć zła rozumiana jest tu jako śmierć gwałtowna, przedwczesna czy nienaturalna.

Interpretacja odbioru śmierci złej oraz towarzysząca temu reakcja społeczności odnosi się do aspektów duchowości. Według ustaleń etnograficznych osoby zmarłe złą śmiercią niekiedy podejrzewano o stawanie się istotami demonicznymi. Tak też po śmierci „wampirami” stać się mogły ofiary morderstw bądź wypadków, mordercy, grzesznicy, osoby uchybiające obyczajowi; nieochrzczone dzieci, kobiety w ciąży lub połogu, czarownice i czarownicy, wreszcie osoby niepełnosprawne, chore albo zwyczajnie odbiegające swoim wyglądem lub zachowaniem od „normy” (Kolczyński, 2003). W celu zabezpieczenia się przed ich szkodliwą działalnością stosowano więc praktyki „antywampiryczne”. Wykonane na pochówku domniemanego „wampira” miały uniemożliwić mu wydostanie się z grobu, a tym samym wyrządzanie krzywd żywym. Przy podejmowaniu problematyki praktyk i pochówków ,antywampirycznych" niemożliwymi do uniknięcia stają się tym samym próby rekonstrukcji wierzeń. Jest to jednak kwestia złożona.

\section{„WAMPIR”, UPIÓR CZY REVENANT?}

Informacje o słowiańskich bytach nadprzyrodzonych po części pochodzą ze źródeł etnograficznych - z czasów zdecydowanie późniejszych niż te, których miałyby dotyczyć. Co więcej, na przestrzeni wieków wierzenia bezsprzecznie ulegały zmianom. Były one spowodowane chociażby chrystianizacją, a następnie umacnianiem nowej religii. Obecność w opisach i klasyfikacjach demonologii słowiańskiej niektórych bytów nadprzyrodzonych najpewniej bezpośrednio wynika z tej tylko kwestii. Trudno jest tym samym stwierdzić, na ile na Słowiańszczyźnie przedchrześcijańskiej rozpowszechniona była wiara w określone istoty demoniczne, obecne w przekazach późniejszych. Istotnie wydaje się, że zapewne istniały jakieś ich wcześniejsze wzorce, które następnie stanowiły podstawę dla nowych wyobrażeń. Ich wyodrębnienie jest jednak trudne lub wręcz niemożliwe ze względu na zmiany kulturowe oraz wynikające $\mathrm{z}$ nich przewartościowania w sferze wierzeniowej i duchowej (Baranowski, 1981, s. 189; Pełka, 1987, s. 145).

Sama „mitologia” słowiańska stanowi w gruncie rzeczy zbiór współczesnych domysłów i dywagacji (Moszyński, 1993). Bezkrytycznemu przekładaniu nowożytnej kultury ludowej na grunt wczesnośredniowieczny brakuje tym samym wiarygodności. Etnografię i folklor ludowy traktować należałoby więc nie dosłownie, a jedynie jak pewnego rodzaju wskazówki z niedomówieniami i metaforami.

Chociaż uznaje się, że pewna wizja wstających z grobu (nie)umarłych musiała istnieć w świadomości Słowian stosunkowo wcześnie (Kolczyński, 2003), niekiedy nadal zwraca się uwagę, że mógł to być element obcy, przejęty z tradycji chrześcijańskiej (Zoll-Adamikowa, 1995, s. 123-126, za: Kolczyński, 2003). Samo to sprawia, że użycie „wampira” do opisu bytów z wierzeń wczesnośredniowiecznych jest dys- 
kusyjne. Zdaje się bowiem nie do końca odwzorowywać czasy, w dalszej kolejności także i specyfikę zjawiska; jego nieprecyzyjność objawia się tym samym zarówno na płaszczyźnie językowej, jak i kulturowej. W związku z tym za nieprecyzyjne lub mylące uznać można wywodzone od niego terminy, takie jak ,antywampiryczny” (mimo jego rozpowszechnienia w literaturze przedmiotu). Jak zwraca uwagę Tomasz Jurek (2016): „określenie «pochówki antywampiryczne» budzi zresztą wątpliwości: chowano wszak domniemanego wampira (nie antywampira), a antywampiryczny charakter miały tylko związane z takim pochówkiem zabiegi".

Uznać można, że przymiotnik „,antywampiryczny” odnosi się jednak nie tyle do samego zmarłego, co do funkcji (charakteru) pochówku, a tym samym do wspomnianych zabiegów. Te zaś w rzeczy samej określać można jako „anty-” czy też „przeciwwampiryczne". Jednak prawidłowość tego pojęcia zależna jest od prawidłowości samego słowa „wampir”.

Jego etymologia jest niejasna, możliwe, że niesłowiańska (Stachowski, 2005), a potrzeba jego zmiany bywa tym samym jasno wyrażana (Gardeła, 2015; 2017, s. 89). Do tego określenie to wiązać należy najwcześniej ze średniowieczem późnym, najpewniej zaś nowożytnością (Kolczyński, 2003). Nie ma zatem podstaw ku temu, aby używać go w kontekście rodzimych wierzeń wczesnośredniowiecznych. Do opisania podobnych „wampirom” istot w Europie Zachodniej występują określenia takie jak revenants czy Wiedergänger. Możliwe, że to nimi należałoby się inspirować przy poszukiwaniach właściwszych odpowiedników. Pamiętać jednak należy, że chociaż wiara $\mathrm{w}$ żywe trupy była obecna w całej Europie, nie była ona niezależnie od kultury taka sama. Edeltraud Aspöck (2008) zwraca uwagę, że słowiańskie „wampiry” w porównaniu z chociażby niemieckimi Wiedergänger (tj. powracającymi umarłymi) miały być bardziej niebezpieczne: nie tylko wracały do świata żywych, lecz aktywnie szkodziły społeczności.

Tym samym wydaje się zasadne zastąpienie „wampiryzmu” i „wampirów” określeniami mniej nacechowanymi kulturowo. Odpowiednie byłoby stosowanie terminów, takich jak ,szkodliwy zmarły” (za Łukaszem Maurycym Stanaszkiem), „powracający umarły” (w nawiązaniu do revenants i Wiedergänger) bądź „(nie) umarły" - w odniesieniu zarówno do opisu samego bytu, jak i jego stanu jednoczesnego życia i nieżycia.

\section{ATYPOWE VERSUS TYPOWE}

Badacze zajmujący się zagadnieniem pochówków ,antywampirycznych” wskazywali na możliwość alternatywnego wytłumaczenia ich nietypowej formy. Zoll-Adamikowa (1971, s. 50-53) wspomina, że przynajmniej część atypowych/,antywampirycznych" elementów pochówku thumaczyć można inaczej niż zabiegami rytualnymi. Tak też pozycja skurczona na boku wynikać można ze śmierci we śnie, częściowe zwęglenie szczątków śmiercią w pożarze; morderstwo tłumaczyć mogłaby obecność między kośćmi ostrych przedmiotów, takich jak ostrza noży. Ułożenie zmarłych na 
brzuchu występować z kolei mogło w pochówkach zbiorowych ludzi zmarłych na zarazę, a wynikać z pośpiesznego i niedbałego deponowania zwłok do grobu. Alternatywą dla dekapitacji „wampira” z kolei mogłoby być odcięcie głowy mieczem (z zaznaczeniem, że w takim przypadku głowa nie spoczywałaby między nogami, pod pachą lub w innym nietypowym miejscu).

Niezależnie od występowania przytoczonych odmiennych interpretacji ważny jest sam fakt wystąpienia wątpliwości. Sceptycyzm zdaje się istotny, tym bardziej w świetle niekiedy sensacyjnego traktowania omawianego fenomenu; co za tym idzie - powściągliwość przy zbyt pobieżnym traktowaniu tematu pozwala uniknąć wnioskowania ad hoc. Mając to na uwadze, w celu zmniejszenia marginesu błędu sugerowane jest niekiedy kierowanie się kryterium ilościowym (Zoll-Adamikowa, 1971, s. 52; Żydok, 2004). U podstaw takiego działania tkwi przekonanie, że o „antywampiryczności” pochówku decydować powinna obecność nie jednej charakterystycznej cechy, lecz zespołu kilku cech ze sobą współwystępujących. Przemysław Żydok (2004), podkreślając istotę kryterium jakościowego, zwrócił uwagę, że niektóre spośród wymienionych cech mogą być bardziej prawdopodobnymi wyznacznikami niż inne, nawet jeżeli te drugie ze sobą współwystępują. Przy założeniu, że pochówki ,antywampiryczne” stanowią pewnego rodzaju podgrupę pochówków atypowych, a więc nie są w danej kulturze zjawiskiem standardowym, nie można badać ich jedynie metodami ilościowymi, statystycznymi. W tym przypadku decydujące byłoby tym samym kryterium jakościowe, o którym wspomina Żydok. Interpretacja na podstawie samych badań ilościowych, bez uwzględnienia jakościowych, a co za tym idzie bez uwzględnienia kontekstu, może prowadzić do błędnej interpretacji. Błędna interpretacja z kolei przekładać się może bezpośrednio na zbyt pochopne zaklasyfikowanie danego pochówku jako „antywampirycznego” w zbiorze grobów atypowych.

Wartym przemyślenia jest jednak samo osadzanie pochówków ,antywampirycznych" w kontekście atypowych. Za kontekst ten przyjąć można przytoczoną na początku niniejszego artykułu definicję. Należałoby zwrócić przy tym uwagę na specyficzny aspekt atypowości, zawierający się w tym, że mówić o niej można jedynie w jasno określonych warunkach. Atypowość nie istnieje sama w sobie, a widoczna staje się tylko wówczas, kiedy zestawiona zostanie z wcześniej zdefiniowaną typowością (Aspöck, 2008). Na tle znormalizowanego obrządku pogrzebowego wczesnośredniowiecznej Słowiańszczyzny pochówki „antywampiryczne” rzeczywiście spełniają kryteria atypowości. Przyjmując jednak, że są to pochówki zarezerwowane dla określonej grupy społecznej (ofiar ostracyzmu społecznego, posądzonych o stanie się po śmierci istotami demonicznymi), uznać można je za typowe. Stosunkowo zunifikowana forma (powtarzające się zabiegi w odniesieniu do pochówku, jak i jamy grobowej), a także domniemane wspólne rytualne znaczenie sugerują, że miały one określone znaczenie wśród Słowian zachodnich. Musiały tym samym funkcjonować $\mathrm{w}$ ich kulturze i być wynikiem świadomego działania. $\mathrm{Z}$ tego też powodu można uznać je za, w pewnym sensie, typowe, a przynajmniej nie tak pod tym względem jednoznaczne. 


\section{PODSUMOWANIE}

Moim zdaniem zasadne jest podwójne rozgraniczenie pochówków „antywampirycznych" - od „wampiryzmu” i atypowości. Jako pierwsze odpowiednie byłoby zastąpienie „wampiryzmu” określeniami, takimi jak ,,szkodliwy zmarły” lub „powracający umarły", w nawiązaniu do zachodnioeuropejskich revenants czy Wiedergänger. Odpowiednią alternatywą mogłoby być określenie „(nie)umarły”. Słowo to ma mało wspólnego z realiami wczesnośredniowiecznej Słowiańszczyzny zachodniej zarówno na płaszczyźnie czysto językowej, jak sugerują językoznawcy (zob. Stachowski, 2005), jak i wierzeniowej. Jego stosowanie może tym samym prowadzić do zbytnich uproszczeń lub niedopowiedzeń.

Drugą kwestią wartą podjęcia jest samo osadzenie pochówków „antywampirycznych" w kontekście atypowości. Zakładając, że nie są zjawiskiem dla kultury Słowian zachodnich standardowym, próby ujmowania i badania ich sugerowanymi niekiedy metodami ilościowymi wydaje się niezasadne. W tym też wypadku należałoby kierować się przede wszystkim kryterium jakościowym, co pozwoliłoby na uwzględnienie kontekstu i uniknięcie błędnej interpretacji.

Zwracając jednak uwagę na to, że groby „antywampiryczne” odkrywane bywają na obszarze całej dzisiejszej Polski, a ich formy są do siebie zbliżone (w takim sensie, że stosowane zabiegi się powtarzają w różnych układach), uznać można, że fenomen praktyk skierowanych przeciwko powracającym (nie)umarłym był wśród Słowian zachodnich stosunkowo powszechny. Aspöck twierdzi wręcz, że wszystkie pochówki atypowe (ang. deviant burials) są przejawem obecnych w danej społeczności wierzeń i praktyk funeralnych (Aspöck, 2008). To z kolei stanowiłoby przyczynek do zmiany sposobu myślenia o pochówkach ,antywampirycznych” - nie tyle jako o atypowych (przynajmniej nie w skali mikro), lecz o typowych, z tym zastrzeżeniem, że typowych dla konkretnej grupy osób przez społeczność żywych potępionych, lecz niekoniecznie (mając na uwadze wcześniejsze kontrowersje) „wampirów”.

\section{BIBLIOGRAFIA}

Aspöck, E.

2008 What Actually Is a 'Deviant Burial'?: Comparing German-Language and Anglophone Research on 'Deviant Burials'. W: E. M. Murphy (red.), Deviant Burial in the Archaeological Record (s. 17-33). Oxford: Oxbow Books.

Baranowski, B.

1981 W kręgu upiorów i wilkołaków. Łódź: Wydawnictwo Łódzkie.

Gardeła, L.

2015 Vampire Burials in Medieval Poland. An Overview of Past Controversies and Recent Reevaluations. Lund Archaeological Review, 21, 107-126.

2017 Bad Death in the Early Middle Ages: Atypical Burials from Poland in a Comparative Perspective. Rzeszów: Oficyna Wydawnicza „Zimowit”. 
Jurek, T.

2016 „Wampiry w średniowiecznej Polsce”, Łukasz Maurycy Stanaszek, Warszawa 2016: [rec.]. Roczniki Historyczne, 82, 227-229.

Kolczyński, J.

2003 Jeszcze raz o upiorze (wampirze) i strzygoni (strzydze). Etnografia Polski, 47(1-2), 211246.

Moszyński, L.

1993 Przedchrześcijańska religia Słowian na Pomorzu na tle ogólnosłowiańskim. Studia Gdańskie, 9, 11-43.

Pełka, L. J.

1987 Polska demonologia ludowa. Warszawa: Iskry.

Stachowski, K.

2005 Wampir na rozdrożach. Etymologia wyrazu upiór $\sim$ wampir w językach słowiańskich. Rocznik Slawistyczny, 55, 73-92.

Stanaszek, Ł. M

2016 Wampiry w średniowiecznej Polsce. Warszawa: Narodowe Centrum Kultury.

Zoll-Adamikowa, $\mathrm{H}$.

1971 Próba periodyzacji wczesnośredniowiecznych praktyk pogrzebowych w Polsce. Archeologia Polski, 16, 541-556.

1995 Die Jenseitsvorstellungen bei den Heidnischen Slawen: Defunciti vivi oder immaterialle Seelen? Przeglad Archeologiczny, 43, 123-126.

Żydok, P.

2004 Wczesnośredniowieczne pochówki antywampiryczne. W: Z. Kobyliński (red.), Hereditatem Cognoscere. Studia i szkice dedykowane Profesor Marii Miśkiewicz (s. 38-66). Warszawa: Wydział Nauk Historycznych i Społecznych Uniwersytetu Kardynała Stefana Wyszyńskiego; Państwowe Muzeum Archeologiczne; Instytut Archeologii Uniwersytetu Warszawskiego.

THE NEED OF RECONCEPTUALIZATION OF EARLY MEDIEVAL BURIALS OF "VAMPIRES" FROM POLAND

\section{Sum mary}

The paper suggests the need of reconceptualization of the early medieval "vampire" burials from Poland. These burials are understood as effects and remnants after performing the so called "anti-vampire" practices; these practices on the other hand directly stem from the social reaction and reception of bad death (that is: sudden or premature death, or death of particular people: usually sinners, witches and outcasts, but also unbaptized children, pregnant women, disabled or sick). "Anti-vampirical" practices could be defined as a social and religious phenomenon within early medieval Slavic culture, and its purpose was to separate the "vampire" from the living, ensuring well-being of the latter.

However, in the academic literature there are few concerns regarding this subject. One of them is the usage of term "vampire", and therefore all terms related to it. Etymology of the word is not clear, however, it was suggested by linguists to be not Slavic. Also, its origins could be rather linked with Late Middle Ages and even modern era - therefore using it in the context of Early Medieval Slavic beliefs is controversial. Because of that it is suggested to use other terms with similar mean- 
ings, such as "returning dead ones" or "(un)dead" (which could be related to both the creature, and its dual state of living and not-living at the same time).

Second concern is the relation of "anti-vampirical" burials to deviant burials. The former could be considered as the latter when viewed very broadly, as "anti-vampirical" burials do not match the description of what is considered normative burial rite for the Early Medieval Poland. However, given the fact that "anti-vampirical" burials and related practices had a specific, known and recognized place within Slavic culture, they could be considered as typical - albeit only for a specific group of people, that is: social pariahs deemed by the rest of society as possible "vampires". 